\title{
Utilização da Trilha Ecológica como Instrumento de Educação Ambiental: Parque da Cidade Dom Nivaldo Monte, Natal/RN
}

\author{
Use of the Ecological Trail as an Environmental Education Instrument: Dom Nivaldo Monte \\ City Park, Natal / RN
}

MACIEL ${ }^{1}$, A. B. C.; LIMA $^{2}$, Z. M. C.; MORAIS ${ }^{3}$, A. C. S.

bia_geo2003@hotmail.com;

\begin{abstract}
Resumo
A importância dada às questões ambientais tem sido crescente e a educação ambiental desempenha papel importante no que se refere à conscientização da sociedade para a preservação da natureza. Atualmente, a educação ambiental vem sendo trabalhada de diversas formas, amparando uma gama de métodos, estratégias e ferramentas que auxiliam no despertar para um auto avaliação do comportamento do homem como sujeito ativo no meio. Com base nesse pressuposto, o presente trabalho avaliou uma dessas ferramentas que é bastante utilizada para a promoção da educação ambiental: a trilha interpretativa. Diante disso, buscou-se compreender a importância da trilha interpretativa como desenvolvimento da educação ambiental no Parque da Cidade. Os procedimentos metodológicos utilizados foram: o levantamento bibliográfico acerca da temática e também por meio da aplicação de questionários com os responsáveis pelos grupos visitantes. Foi verificado que grande parcela dos entrevistados afirmaram ter aprendido muitas informações novas relacionadas ao ambiente do parque (fauna, flora). Observou-se também que eles se sentiram motivados a conservar e preservar o meio ambiente e percebeu a importância dessas em busca de uma melhor qualidade vida e também para o ambiente. Sendo assim, as trilhas interpretativas demonstraram ser uma ferramenta com um potencial transformador.
\end{abstract}

Palavras-chave: Educação Ambiental; Trilha interpretativa; Parque da Cidade Dom Nivaldo Monte/Natal - RN.

\begin{abstract}
The importance given to environmental issues has been increasing and environmental education plays an important role in raising society's awareness of nature conservation. Currently, environmental education has been worked in several ways, supporting a range of methods, strategies and tools that help in the awakening to a self assessment of the behavior of man as an active subject in the environment. Based on this assumption, the present study evaluated one of these tools that is widely used for the promotion of environmental education: the interpretative trail. In view of this, we sought to understand the importance of the interpretive trail as a development of environmental education in the City Park. The methodological procedures used were: a bibliographical survey about the subject and also through the application of questionnaires with those responsible for the visiting groups. It was verified that a large part of the interviewees stated that they learned a lot of new information related to the environment of the park (fauna and flora). It was also observed that they felt motivated to conserve and preserve the environment and realized the importance of these in search of a better quality life and also for the environment. Thus, the interpretive trails have proved to be a tool with transformative potential.
\end{abstract}

Keywords: Environmental education; Interpretive track; Park of the City Dom Nivaldo Monte / Natal - RN.

\section{INTRODUÇÃO}

Diante de uma sociedade altamente consumista, onde nota-se que os valores predominantes dizem respeito ao ter, enfatizando o competir, o dominar e o descartar. A comodidade e a vida corrida e sem tempo reforçam estas atitudes e marca um estilo de vida, um padrão cultural (ZANETI, 2003). Verifica-se que os valores que dizem respeito ao ter cristalizam ações no sentido 
de possuir, guardar, segurar e reter, ao passo que valores que dizem respeito ao ser permitem compartilhar, doar, cooperar e respeitar a integridade do outro e da natureza com inteireza, solidariedade e justiça, conforme aponta Zaneti (2003).

As atividades humanas devem ser consideradas dentro de um contexto sociocultural consciente e capaz de mobilizar a força política e econômica para respeitar os limites do meio natural de modo que seus recursos sejam utilizados pelas gerações futuras, o que conhecemos como desenvolvimento sustentável. Por esse motivo, a importância dada às questões ambientais deve ser cada vez mais crescente bem como a necessidade da busca dos sentidos sobre o papel da educação ambiental para as mudanças sociais, que advém do envolvimento das mais diversas áreas do conhecimento e do engajamento do poder público, de profissionais, bem como da comunidade, visando promover inter-relações do meio natural com o social (JACOBI, 2003).

A Educação Ambiental corrobora com as práticas, no sentido de complementar as ações na busca da sensibilização e conscientização das pessoas da sua responsabilidade enquanto cidadãos planetários desenvolvendo meios de diminuir os danos sociais e ambientais causados ao planeta. É necessário que o fazer educativo, segundo Carvalho (2001), aconteça no sentido de acessar valores ambientais da sociedade. Assim, a educação funcionaria como uma prática interpretativa, que desvela e produz sentidos e contribui para a constituição de um horizonte compreensivo das relações sociedade-natureza e para a invenção de um sujeito ecológico (CARVALHO, 2001, p.35).

Sorrentino et. al (2005, p.287), aborda que é necessária uma urgente transformação social e que a educação ambiental como ferramenta para minimizar a desigualdade social, da apropriação capitalista e funcionalista da natureza e da própria humanidade. Ou seja, a educação ambiental pode auxiliar, através de diversas ferramentas, os agentes sociais no despertar para uma auto avaliação de seu comportamento como sujeito ativo no meio. Ao realizar a educação ambiental como prática interpretativa que desvela e produz sentidos lança-se luz naquilo que pode estar velado dentro do sistema. A educação ambiental desenvolve-se na escola, na comunidade local, nos parques, em todos os lugares.

Diante disso, a educação ambiental deve ser "direcionada para uma cidadania ativa considerando seu sentido de pertencimento e co-responsabilidade" (SORRENTINO et. al, 2005, p.289). Então como fazer educação ambiental considerando o sentido de pertencimento e coresponsabilidade? Fazendo o indivíduo sentir-se parte do meio.

Uma das ferramentas utilizadas para alcançar esse objetivo é a realização de trilhas interpretativas. As trilhas têm sido muito difundidas, especialmente em áreas verdes, tais como em unidades de conservação, buscando aliar ao lazer de seus visitantes, uma atividade educativa (DI TULLIO, 2005). A trilha interpretativa visa o contato íntimo do homem com o meio através de um 
interlocutor que se baseia num roteiro predefinido para transmitir a informação ambiental para um público-alvo. Esse contato direto com a natureza através de trilhas interpretativas pode ser uma ferramenta ou estratégia de educação ambiental quando bem planejada. Tomazello e Ferreira (2001) abordaram esse aspecto do processo educativo através do contato direto com a natureza no contexto da educação ambiental dizendo:

\begin{abstract}
A educação no ambiente reconhece que os comportamentos vêm guiados muito mais pelas nossas emoções e valores do que por nossos conhecimentos, portanto é necessário não só oferecer aos educandos informações como propor experiências que reconstruam a conexão entre o homem e a natureza. Nesse caso, a teoria implícita é que o vínculo emotivo com o meio ambiente será suficientemente forte para promover mudanças de comportamento. Com frequência, a educação no ou através do ambiente invoca a proteção e a conservação de uma natureza que, seguramente, sobreviverá à nossa espécie (TOMAZELLO; FERREIRA, 2001, p.202).
\end{abstract}

As Unidades de Conservação (UC’s) constituem, portanto, um ambiente propício para a realização de trilhas interpretativas, sobretudo em UC's da categoria parques, onde existe uma estrutura administrativa e física que possibilita o planejamento e execução dessa atividade (BRASIL, 2000). Baseado nisso, o Parque Natural Municipal Don Nivaldo Monte (mais conhecido como Parque da Cidade) localizado no município de Natal-RN, foi escolhido para fins deste estudo, pois é um parque que possui um centro administrativo que coordena atividades de educação ambiental e, dentre elas, a realização de trilhas interpretativas. Além disso, o parque vem ganhando notoriedade pela população natalense e cada vez mais grupos do município e de cidades vizinhas visitam e realizam trilhas interpretativas no parque.

Apesar da frequência com que as trilhas interpretativas são utilizadas e de existir relatos sobre o uso das mesmas como uma ferramenta para a educação ambiental, existe uma carência de estudos que verifiquem a sua validade e eficácia no objetivo de promover uma educação ambiental. Verificar com critérios qual tem sido a eficácia da utilização de trilhas interpretativas e quais aspectos podem ser intervindos para que elas possam ser utilizadas de forma adequada e proveitosa torna-se de grande importância.

O presente trabalho pretende, portanto, avaliar a realização de trilhas interpretativas no Parque da Cidade como uma ferramenta para a promoção da educação ambiental junto aos visitantes. Assim como avaliar a metodologia utilizada ao longo das trilhas para a disseminação das informações sobre as características ambientais (geológicas, pedológicas, geomorfológicas, fauna e flora) e a capacidade de influência dessa metodologia na formação de uma nova visão ambiental dos visitantes; e coletar informações junto aos visitantes das trilhas a respeito de suas opiniões sobre o seu papel para a educação ambiental.

Com esse trabalho pretende-se contribuir com a avaliação do papel e da importância das trilhas interpretativas para a educação ambiental dos grupos visitantes, sugerir formas de como o 
potencial educativo dessas trilhas pode ser melhor aproveitado, sugerir informações e estratégias de abordagem do visitante na realização da trilha. Pretendemos, por fim, contribuir com melhorias e adequações na realização das trilhas para atingir o objetivo de uma educação ambiental transformadora junto aos grupos que visitam do Parque da Cidade Don Nivaldo Monte.

\section{EDUCAÇÃO AMBIENTAL E SUAS FERRAMENTAS}

\subsection{Educação e Ambiente}

A educação ambiental tem sido um tema trabalhado em diversas teses e dissertações associadas às mais diversas áreas, dentre as quais podemos citar: ciências ambientais, gestão ambiental, saúde pública, geociências, psicologia, serviço social, saneamento, filosofia e até mesmo a engenharia (REIGOTA, 2007; QUINTAS, 2006; LAYARGUES, 2000; PASTUK, 1993). Desse modo, vemos que a educação ambiental como temática alcança uma série de áreas do conhecimento que, em algum momento, acabam por se depararem em suas abordagens teóricas ou práticas com o importante papel da educação ambiental.

Entretanto, para entender o que é educação ambiental precisa-se antes conceber um sentido para "ambiente" e para "educação". Trata-se de conceber a EA num contexto mais amplo, o da cidadania planetária (GADOTTI, 2000). A EA deve ser acima de tudo, um ato político voltado para a transformação econômica, social e ambiental da sociedade.

O ser humano através de suas vivências e experiências cotidianas tem a necessidade de ser parte de um meio. Meio no qual ele seja um sujeito ativo e possa estabelecer relações múltiplas, com diferentes percepções que acabarão por interferir em seu comportamento social e ecológico. Dessa maneira, pode-se invocar o conceito de “ambiente” expresso por IBASE (2006) como sendo:

(...) um espaço percebido, com diferentes escalas de compreensão e intervenção, em que se operam as múltiplas relações ecológicas e sociais, formando a unidade natural. $\mathrm{O}$ ambiente não é, portanto, o espaço natural independente da ação social, mas o resultado de interações complexas e dinâmicas, limitadas em recortes de espaço e tempo que permitem a construção do sentido de localidade, territorialidade, identidade, pertencimento e de contextualização para os agentes sociais (IBASE, 2006, p.10).

Antes de considerar um "meio ambiente" o espaço é também um meio de relações diversas que irão construir o sujeito social, o agente. Assim sendo, não se pode considerar o meio ambiente apenas no seu aspecto físico ou do ponto de vista das características naturais e ecológicas ou da paisagem natural. $\mathrm{O}$ homem tem seus costumes e conhecimentos moldados por suas relações sociais mantidas estabelecidas neste meio, independente de ser natural ou urbano e não é diferente quando tratamos de educação. Dessa forma, o IBASE (2006), afirma que a educação ambiental, 
É uma prática social cujo fim é o aprimoramento humano naquilo que pode ser aprendido e recriado a partir dos diferentes saberes existentes em uma cultura, de acordo com as necessidades e exigências de uma sociedade (IBASE, 2006, p. 10).

Quando falamos de educação ambiental não é diferente. Ela também pressupõe a prática social, essa inter-relação entre o espaço natural percebido pelo homem e toda a rede de saberes e percepções advindas desta experiência, do contato, das sensações e da dinâmica que se estabeleceu com o meio (JACOBI, 2003). A educação ambiental não é simplesmente uma forma de educar, segundo Sauvé (2005) a educação ambiental:

\begin{abstract}
(...) não é simplesmente uma "ferramenta" para a resolução de problemas ou de gestão do meio ambiente. Trata-se de uma dimensão essencial da educação fundamental que diz respeito a uma esfera de interações que está na base do desenvolvimento pessoal e social: a da relação com o meio em que vivemos, com essa "casa de vida" compartilhada. A educação ambiental visa a induzir dinâmicas sociais, de início na comunidade local e, posteriormente, em redes mais amplas de solidariedade, promovendo a abordagem colaborativa e crítica das realidades socioambientais e uma compreensão autônoma e criativa dos problemas que se apresentam e das soluções possíveis para eles (SAUVÉ, 2005, p.317).
\end{abstract}

Assim sendo, devemos compreender que fazer educação ambiental não é dissociar homem de meio ambiente através de abordagens metodológicas que não consideram esses elementos fundidos num meio, espaço ou território. Abordar problemáticas ambientais não é simplesmente discuti-las à luz da ciência ambiental pura propriamente, mas compreender que por traz de cada problemática ambiental existem atores sociais que estabelecem relações complexas com o meio (seja natural ou social/humano/antrópico) dando origem a cada uma dessas problemáticas (SAUVÉ, 2005).

Loureiro (2004, p.16) afirma que "a educação ambiental que incorpora a perspectiva dos sujeitos sociais permite estabelecer uma prática pedagógica contextualizada e crítica, que explicita os problemas estruturais de nossa sociedade". E, que de igual modo, as soluções para tais problemáticas só serão possíveis através da compreensão de tal relação dentro de um processo educativo que seja transformador do ponto de vista das relações sociais e desta com o seu meio, colocando em prática, portanto, uma educação ambiental crítica.

\title{
2.2 Ferramentas de Educação Ambiental
}

Partindo para as soluções, existe uma série de ferramentas e abordagens na literatura com que se pode instrumentalizar a educação ambiental de acordo com a sua finalidade e seu contexto problemático-cultural. Estas ferramentas auxiliam a colocar em prática às dinâmicas sociais com o meio, pois o objeto da educação ambiental é incentivar nossa relação com o meio ambiente e o resultado disso é uma educação crítica e transformadora. 
Além disso, a educação ambiental relaciona-se com diversos campos do conhecimento, o que proporciona um leque de opções onde se pode abordar a temática considerando as suas aplicabilidades, trazendo sempre à tona o papel do agente social e visando uma mudança interna através de suas experiências externas (com o meio). Segundo Sauvé (1997), existem diferentes concepções sobre a educação e sobre meio ambiente, além de suas relações que ajudam a prática de um desenvolvimento sustentável, e essa diversidade deve ser considerada de modo positivo devendo provocar uma reflexão crítica sobre as formas de pôr em prática a educação ambiental. Sobre estas formas de trabalhar a educação ambiental Sauvé (2005, p.319) declara que "cabe a cada ator definir seu "nicho" educacional na educação ambiental, em função do contexto particular de sua intervenção, do grupo alvo a que se dirige e dos recursos de que dispõe".

Assim sendo, ao longo das décadas de estudos e pesquisas realizadas na área de educação ambiental observamos o uso dos mais diversos recursos ou ferramentas para se trabalhar a educação ambiental em diversas situações de intervenção. Algumas ferramentas para a prática da educação ambiental são mostradas no quadro 1 abaixo.

Quadro 1 - Exemplos de ferramentas utilizadas em educação ambiental. Autor: Ana Clézia Simplício de Morais, Ago./2015.

\begin{tabular}{|c|c|c|}
\hline FERRAMENTA & OBJETIVO & REFERENCIA \\
\hline $\begin{array}{l}\text { Uso de tecnologias da } \\
\text { informação e } \\
\text { comunicação }\end{array}$ & $\begin{array}{l}\text { Explorar as potencialidades das novas } \\
\text { tecnologias para a sensibilização e } \\
\text { conhecimento } \text { de ambientes } \\
\text { diferenciados. }\end{array}$ & $\begin{array}{l}\text { RODRIGUES, G. S. de S. C.; COLESANTI, } \\
\text { M. T. de M. Educação ambiental e as } \\
\text { novas tecnologias de informação e } \\
\text { comunicação. Sociedade \& Natureza, } \\
\text { Uberlândia, } 20 \text { (1): } 51-66 \text {, jun. } 2008 \text {. }\end{array}$ \\
\hline $\begin{array}{l}\text { O uso da fotografia, } \\
\text { artes plásticas e } \\
\text { instrumentos musicais }\end{array}$ & $\begin{array}{l}\text { A utilização da fotografia, artes } \\
\text { plásticas, instrumentos musicais } \\
\text { artesanais, jogos e danças para a } \\
\text { percepção e valorização do meio } \\
\text { ambiente. }\end{array}$ & $\begin{array}{l}\text { SENAGA, Mário; MARTINI, Priscilla. } \\
\text { Governo do Estado de São Paulo. Sistema } \\
\text { Ambiental Paulista. O uso da fotografia, } \\
\text { artes plásticas e instrumentos musicais de } \\
\text { plástico na educação ambiental. São Paulo, } \\
2004 \text {. }\end{array}$ \\
\hline $\begin{array}{l}\text { Uso de material em } \\
\text { braile e dos sentidos }\end{array}$ & $\begin{array}{l}\text { Permitir o acesso à informação sobre } \\
\text { educação ambiental para cegos, bem } \\
\text { como estratégias sensitivas como forma } \\
\text { de trabalhar a educação ambiental com } \\
\text { os deficientes visuais. }\end{array}$ & $\begin{array}{l}\text { MACIEL et. al. Metodologias de uma } \\
\text { educação ambiental inclusiva. Escola de } \\
\text { Gestão Pública. Secretaria Municipal de } \\
\text { Administração de Porto Alegre. Revista } \\
\text { EGP. } \\
\text { http://www2.portoalegre.rs.gov.br/sma/revist } \\
\text { a_EGP/Metodologia_Jaqueline_outros.pdf }\end{array}$ \\
\hline $\begin{array}{l}\text { Uso de Jornal Mural e } \\
\text { Cordel }\end{array}$ & $\begin{array}{l}\text { Criação de jornal mural e de cordel para } \\
\text { retratar problemas ambientais } \\
\text { enfrentados por pequenos agricultores. }\end{array}$ & $\begin{array}{l}\text { Fonte: } \\
\text { http://www.sjc.sp.gov.br/noticias/noticia.asp } \\
\text { x?noticia_id=18856 }\end{array}$ \\
\hline
\end{tabular}

Há um número crescente de práticas educativas que insere novas dimensões de pesquisa ou de reflexão em suas intervenções no decorrer dos últimos anos. Isso é positivo, uma vez que se abre um leque de opções de recursos que podem ser utilizados. Existe na literatura registros do uso de recursos diversos, abordagens diferenciadas ou metodologias tais que proporcionaram meios de 
alcance de grupos inseridos nos mais diversos contextos levando até eles conhecimento, incentivo da participação ativa e melhoria da qualidade de vida.

Entretanto, vale salientar que para fazer uso de ferramentas que auxiliem a prática da educação ambiental ou mesmo metodologias que facilitem o aprendizado depende de alguns fatores, tais como: o público alvo, a temática ou as temáticas que serão trabalhadas, o contexto sociocultural, bem como do objetivo que se pretende atingir. Estes pontos precisam estar bem definidos e ajustados a fim de que o sucesso do programa de intervenção seja alcançado e produza a sensibilização e transformação almejada (SAUVÉ, 2005).

Além disso, considerar o mundo em constante transformação é importante para perceber quando é necessário fazer uma avaliação dos métodos ou ferramentas utilizadas. Ser sensível às mudanças, interpretar, conhecer, agir e integrar ações em prol de uma educação ambiental realizada conforme cada contexto socioeconômico e cultural é um passo importante para a construção de uma sociedade mais consciente de seu papel ativo no meio ambiente, como aponta Sauvé (2005). Dentre tantas ferramentas, as trilhas interpretativas constituem uma importante atividade, pois são bastante conhecidas e utilizadas no contexto da educação ambiental. Realizar trilhas em espaços naturais gera uma diversidade de possibilidades educativas, uma vez que podemos explorar temas das mais diversas áreas do conhecimento, tais como: conservação, fauna, flora, geografia, geologia, ecologia, urbanismo, história, entre outros.

Outro aspecto muito importante a ser explorado ao longo das trilhas são as relações sociais estabelecidas com o meio observado. Refletir sobre as relações do homem com meio natural torna possível entender que tipos de intervenções que aquela área pode ter sofrido ou sob que influência ainda se encontra, seja pelo uso direto ou indireto do espaço através das relações estabelecidas, como demonstra Sauvé (2005).

Fazer um resgate histórico de como aquela área visitada se tornou o que é bem como as pressões antrópicas por ela sofridas, ou a sua relação com a comunidade circundante, promove uma profunda reflexão sobre a relação do homem com o meio ambiente e seu poder transformador. Isso ajuda a compreender os conflitos e desafios enfrentados neste espaço natural. E, segundo Sampaio e Guimarães (2009), entender a natureza que nos circunda diz respeito também a entender as disputas em torno, por exemplo, de como um território deveria ser ocupado, protegido, modificado, preservado ou transformado. A realização de trilhas interpretativas permite promover tal reflexão.

O autor destacou nesse conceito o papel do monitor como um agente social que tem a função de ser um veículo transmissor de informação e de transformação. A trilha, por ser uma atividade ao ar livre, faz uso de elementos encontrados no ambiente natural objetivando incentivar o desenvolvimento dos sentidos em cada indivíduo participante. 
Mas afinal, como podemos definir o que é uma trilha interpretativa? Steil et al. (2010, p.56) diz que "as trilhas são constituídas pelo movimento de corpos humanos se deslocando pelos caminhos traçados no espaço e pelas narrativas dos monitores, que preenchem com sentidos humanos os silêncios da paisagem".

Assim sendo, a trilha interpretativa se constitui uma ferramenta de ensino experiencial, proporcionando, por exemplo, a um grupo escolar, a vivência com os conteúdos estudados na escola. As mesmas são capazes ainda de proporcionar aprendizado e sensibilização, ao promover o contato direto com o meio ambiente (SANTOS et. al., 2012).

Além disso, a implantação de trilhas pode contribuir para um melhor relacionamento da população local com os recursos naturais da região, através do conhecimento da importância da preservação local, das potencialidades existentes na área e de como aquela área beneficia à comunidade do entorno se houver um programa de educação ambiental para a comunidade.

\section{CARACTERIZAÇÃO DAS TRILHAS DO PARQUE DA CIDADE, NATAL/RN}

O Parque Natural Municipal da Cidade do Natal Dom Nivaldo Monte foi criado através do Decreto Municipal No 8.078, de 13 de dezembro de 2006 e ampliado pelo Decreto № 8.608 de 11 de dezembro de 2008, é a primeira unidade de conservação ambiental municipal. Foi oficializado como Unidade de Conservação pelo Dec. № 9.481 de 25 de agosto de 2011. Está localizado na Zona de Proteção Ambiental 1 (ZPA-1), com uma área de 136,54 hectares que abrange os bairros de Pitimbu, Candelária e Cidade Nova (NATAL, 2014), conforme Figura 1.

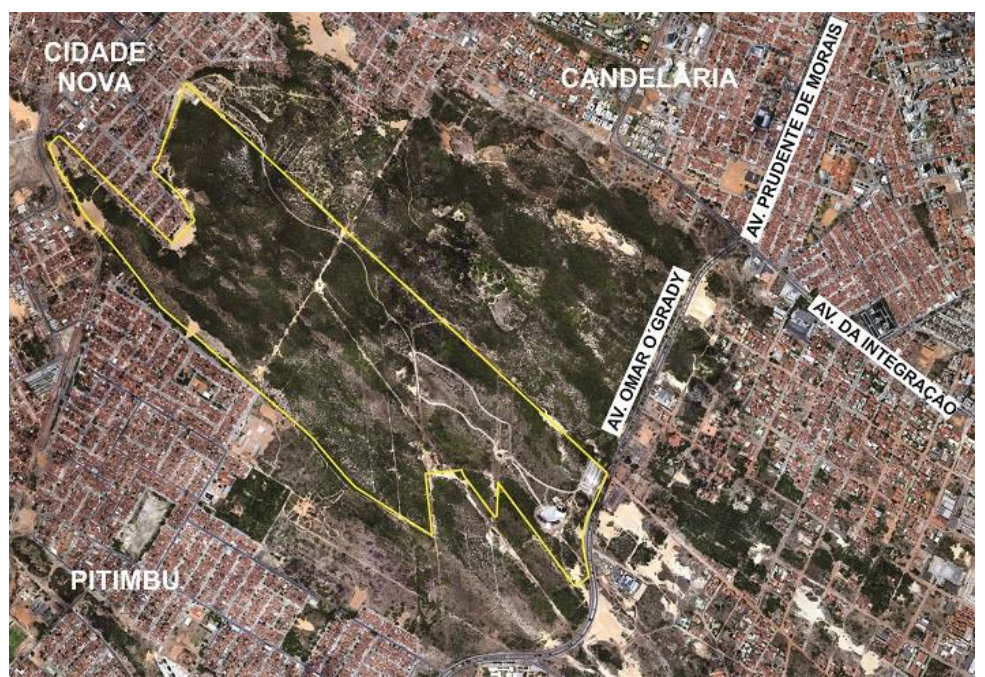

Figura 1- Localização do Parque da Cidade Dom Nivaldo Monte. A área total da unidade de conservação está circulada em amarelo. Fonte: http://www.natal.rn.gov.br/parquedacidade/paginas/ctd-482.html 
O Parque possui dois acessos públicos, um pelo lado leste (Avenida Prefeito Omar O'Grady - Candelária) e outro pelo lado oeste (Rua Santo Amaro - Cidade Nova). Essa unidade de conservação tem uma importância relevante de conservar os recursos naturais, com destaque para a proteção do manancial de água subterrâneo, apontado por especialistas como um dos mais importantes de Natal (MEDEIROS, 2015).

As trilhas existentes no Parque da Cidade têm uma extensão total de 2.605 m (Figura 2), sendo que quatro delas são pavimentadas, disponíveis para caminhada, corrida e passeio de bicicleta sem a obrigatoriedade da presença de um guia. Ao longo das trilhas pavimentadas encontramos estruturas de apoio conhecidas como pontos de descanso, onde há presença de banheiros e bebedouros para o visitante. As trilhas naturais têm seu percurso realizado pela vegetação existente, sendo obrigatório o acompanhamento de um guia e tendo seu uso restrito sob regras de manejo.

As trilhas pavimentadas são: a) Trilha Nascente, com um curto percurso de 305 metros; b) Trilha do Vento, com 645 m; c) Trilha do Lagarto, com 520 metros e d) Trilha do Pôr-do-Sol, com 890 metros. As trilhas naturais são: a) Trilha Bromélia, com 300m de extensão; b) Trilha do Preá, com $800 \mathrm{~m}$ e c) Trilha da Embaúba, com 1.600m.

As trilhas pavimentadas são as mais visitadas, tanto por visitantes independentes quanto por grupos de visitantes agendados, como escolas e grupos sociais. Isso acontece porque as trilhas naturais são mais restritas devido às limitações propostas pelo setor de manejo a fim de evitar impactos ambientais, que restringe a realização desta trilha para os fins de semana e com um número limitado de participantes.

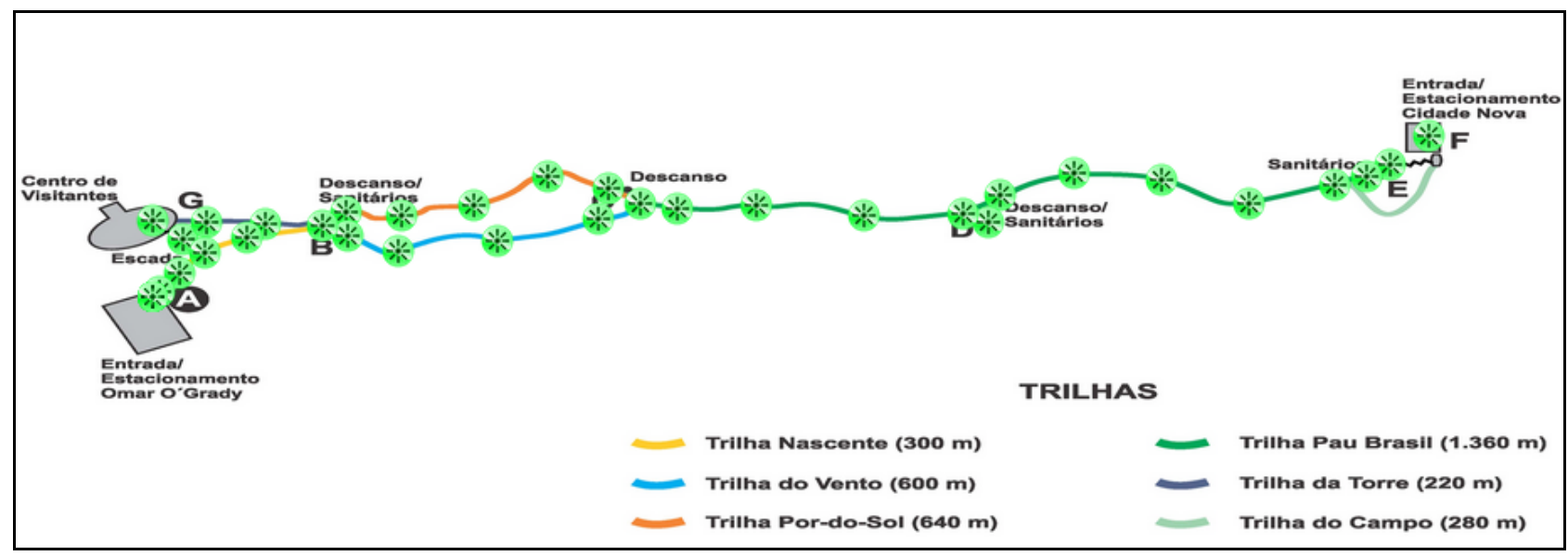

Figura 2- Esquema do percurso total das trilhas pavimentadas. Fonte: https://natal.rn.gov.br/parquedacidade/paginas/ctd-1072.html

A trilha mais utilizada pelos grupos de visitantes, escolas a ser realizada é a que engloba o caminho de ida pela Trilha Pôr-do-sol e voltando pela Trilha do Vento, a qual foi objeto de estudo. 
Para fins deste estudo apenas as trilhas pavimentadas, uma vez que elas são as trilhas com maior frequência de visitas.

\section{METODOLOGIA}

Os procedimentos metodológicos do presente artigo tiveram por base uma pesquisa exploratória, onde foram seguidos dois caminhos: trabalho de gabinete e o trabalho empírico, como descrito abaixo (Figura 3). O trabalho de gabinete consistiu no levantamento bibliográfico de artigos científicos a respeito de temáticas associadas à educação ambiental além de exemplos de intervenção de mesma natureza que, no caso, consistiu da realização de trilhas interpretativas como ferramenta de educação ambiental. Além disso, foram realizadas análises e discussão dos questionários aplicados aos responsáveis pelos grupos de visitantes que realizaram as trilhas.

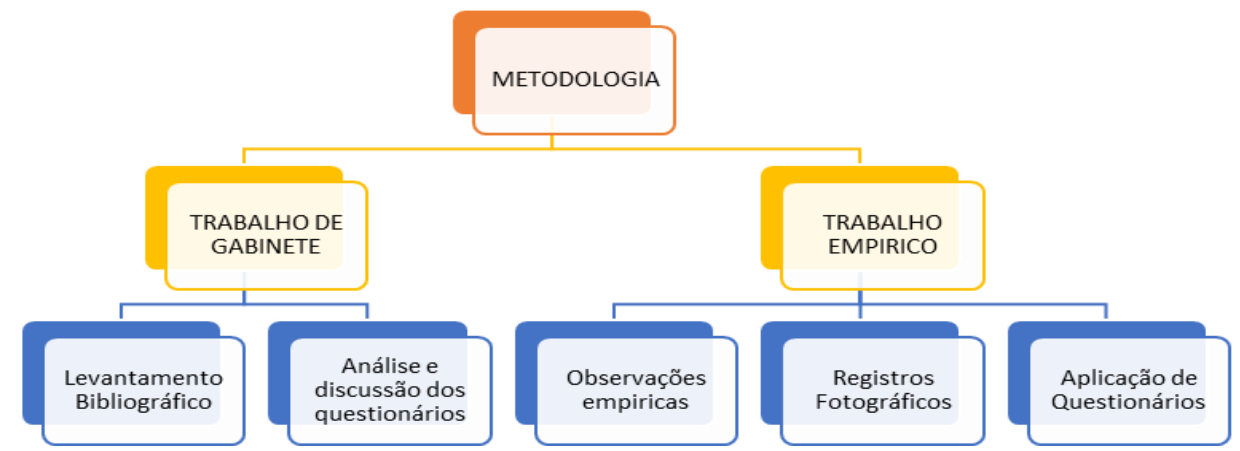

Figura 3 - Organograma da Metodologia do TCC. Elaboração: Ana Clézia Simplício Morais (Set/2015).

O trabalho empírico consistiu na observação da realização das trilhas, a fim de verificar o papel do guia no acolhimento, orientações e informações transmitidas, bem como a metodologia utilizada ao longo das trilhas e o papel das mesmas como uma ferramenta de educação ambiental. Foram realizados também registros fotográficos dos momentos de recepção do grupo, da caminhada nas trilhas, das instruções do guia e de outros aspectos relevantes no momento da caminhada (Figura 4). Por fim, foi feita a aplicação de questionários avaliativos da trilha para os responsáveis pelo grupo que realizaram a trilha no Parque da Cidade. Esse questionário avaliativo consta de perguntas de múltipla escolha e perguntas livres, onde se avaliará a trilha, a metodologia utilizada pelo guia, as informações transmitidas e a postura do guia, a fim de fornecer um cenário do uso da trilha como ferramenta na promoção da educação ambiental neste parque.

Foi aplicado um total de 21 questionários entre os meses de Agosto e Novembro de 2015, com os responsáveis pelos grupos visitantes que realizaram trilhas ecológicas pavimentadas no turno matutino. Esse turno foi escolhido porque a trilha ecológica é realizada assim que se inicia a visita, o que torna possível a aplicação dos questionários uma vez que os professores e demais 
acompanhantes do grupo estão mais disponíveis a responderem o questionário após a trilha quando chegam para o momento de descanso na área de convivência e ainda realizarão as demais atividades. No turno vespertino a trilha é a última atividade a ser realizado, o que inviabiliza a aplicação dos questionários uma vez que o grupo já está de saída do parque não havendo tempo hábil para a sua aplicação após a trilha (Figura 4).
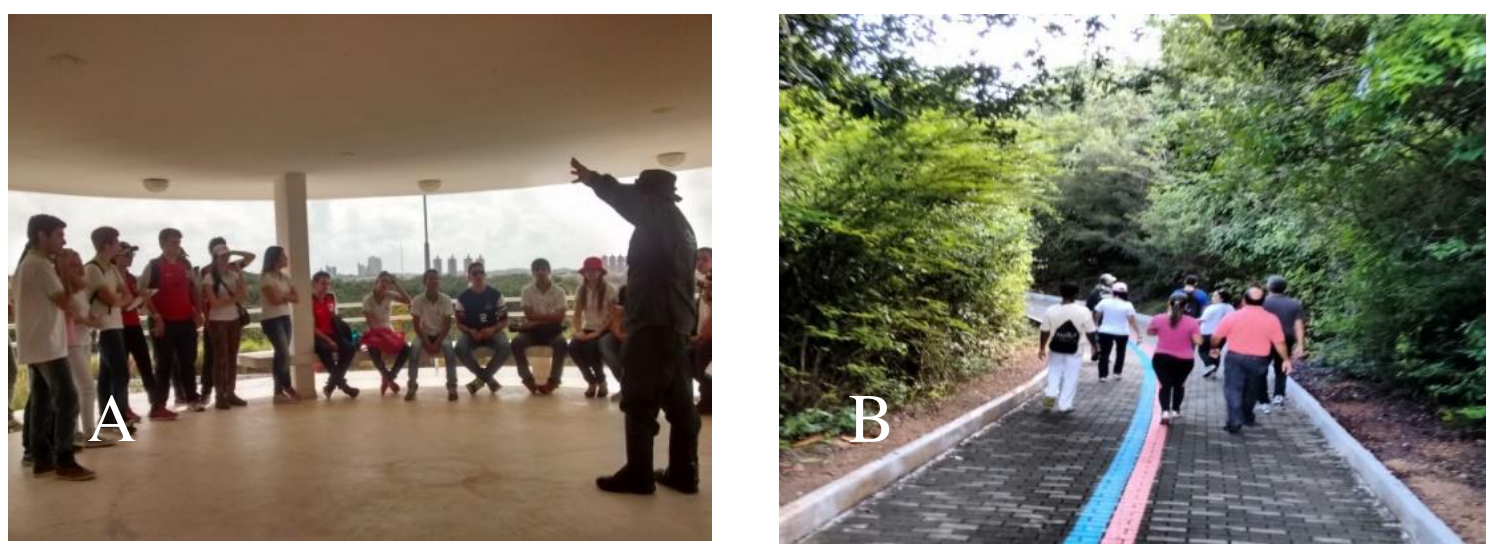

Figura 4 - Parada para explicações (A) / Percurso ao longo da trilha (B). Fotos: Ana Clézia Simplício de Morais, Ago./2015.

A observação da realização das trilhas consistiu em acompanhar o guia com o grupo de visitantes que agendaram a trilha previamente e foi feita várias anotações a respeito de aspectos relacionados a: a. Horário de realização da trilha; b. Nome do guia da trilha; c. Nome da trilha; d. Nome da instituição participante da trilha; e. Número de pessoas que estão realizando a trilha; f. Faixa etária dos participantes da trilha; g. Objetivo da realização da trilha; h. Número de responsáveis acompanhando os alunos na trilha; i. Onde e como acontece o acolhimento do grupo para a trilha; j. Duração da trilha; k. Temas abordados na trilha; 1 . Pontos de parada. O questionário avaliativo da trilha consistiu de perguntas objetivas - com alternativas de resposta - e perguntas abertas, aplicado com os professores/responsáveis pelo grupo de visitantes. As perguntas do questionário terão o objetivo de avaliar a importância da trilha. Além dos questionários algumas informações sobre as trilhas foram coletadas junto aos funcionários do parque.

\section{RESULTADOS E DISCUSSÕES}

\subsection{Caracterização do Público Entrevistado}

Como se pode observar (Gráfico 01) a maioria dos entrevistados possui nível superior completo e nível de pós-graduação, sendo esta última categoria a mais representativa, com um total de 11 entrevistados. Somando-se o número de graduados e pós-graduados temos o correspondente a mais de $85 \%$ dos entrevistados. Isso ocorre porque os responsáveis pelo grupo de alunos visitantes 
são, em sua maioria, professores (Gráfico 02) e para atuação nesta função é requerido um nível mínimo de graduação, ou seja, superior completo.
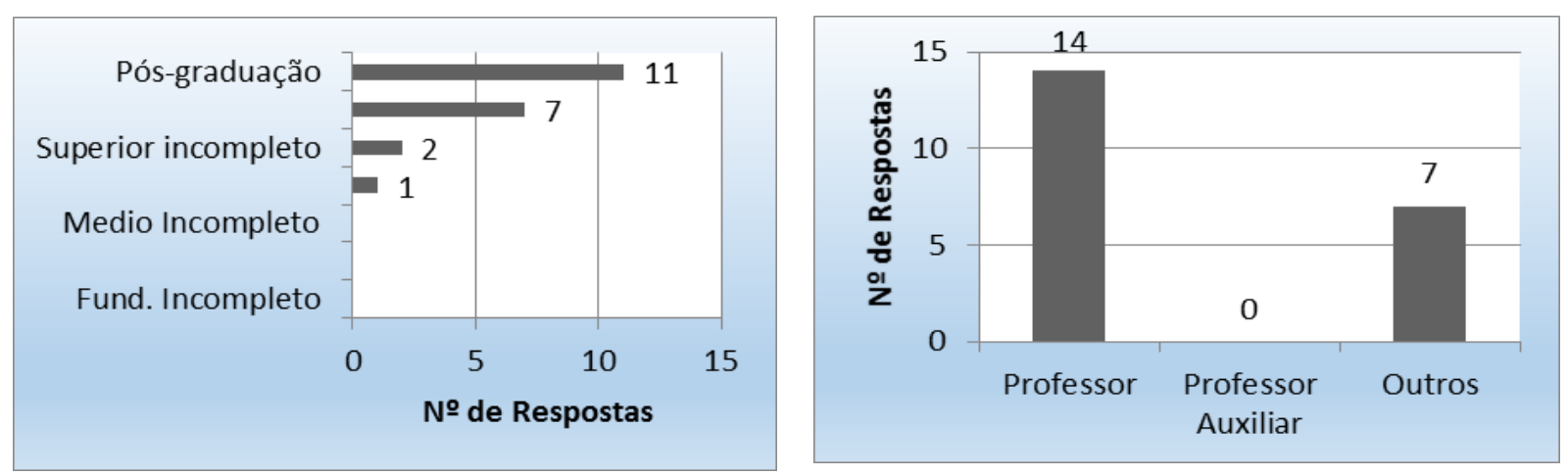

Gráfico 01 - Nível de escolaridade dos entrevistados. Gráfico 02 - Função desempenhada pelo entrevistado. Fonte: Pesquisa de campo (2015).

No gráfico 02 observamos que a maioria dos entrevistados foi professores, sendo que a categoria outros englobam profissionais diversos que também acompanharam os grupos nas visitas, tais como: diretor, coordenador, enfermeira, nutricionista, mediador de leitura, entre outros, e que geralmente são profissionais de nível superior também.

O público que realiza visitas ao parque se caracteriza por grupos sociais, grupos de idosos, ONG's e grupos escolares, tanto de escolas públicas quanto privadas, sendo sua maioria grupos de escolas públicas, segundo informações de funcionários do Centro de Educação Ambiental. Isso ocorre em parte porque o parque já possui há 2 anos uma parceria com a Secretaria Municipal de Educação, através do Projeto Pelotão da Cidadania, que todos os anos levam diversas turmas de escolas públicas municipais para visitarem o parque.

De acordo com os dados coletados, a média de pessoas presentes nos grupos de visitantes foi de 33 pessoas, sendo acompanhados por uma média de 4 responsáveis, entre professores, coordenadores, diretores e outros. Foi constatado que o período de 4 meses (Agosto a Novembro) a maior parte dos grupos visitantes apresenta idade variando entre 10 e 20 anos, ou seja, o grupo é representado em sua maioria por crianças, adolescentes e jovens. Isso pode ocorrer devido ao fato das trilhas apresentarem certa dificuldade para um público de idade inicial, ainda sem uma capacidade locomotora completamente desenvolvida e também para idosos já em idade mais avançada, uma vez que a acessibilidade para este grupo nas trilhas seria mais dificultosa, dando preferência a visitas em outras áreas com características mais acessíveis a estes grupos. Entretanto, vale salientar que o parque dispõe de um carro para acessibilidade deste público a outras áreas de convivência presentes no parque tais como: o pátio de eventos, a biblioteca, a sala de exposições, o mirante e a lanchonete. 


\subsection{Avaliação da Trilha Interpretativa}

Perguntamos aos entrevistados qual era o grau de importância de estar visitando o parque de um modo geral, e grande maioria atribuiu que é muito importante uma visita desta natureza (Gráfico 03).

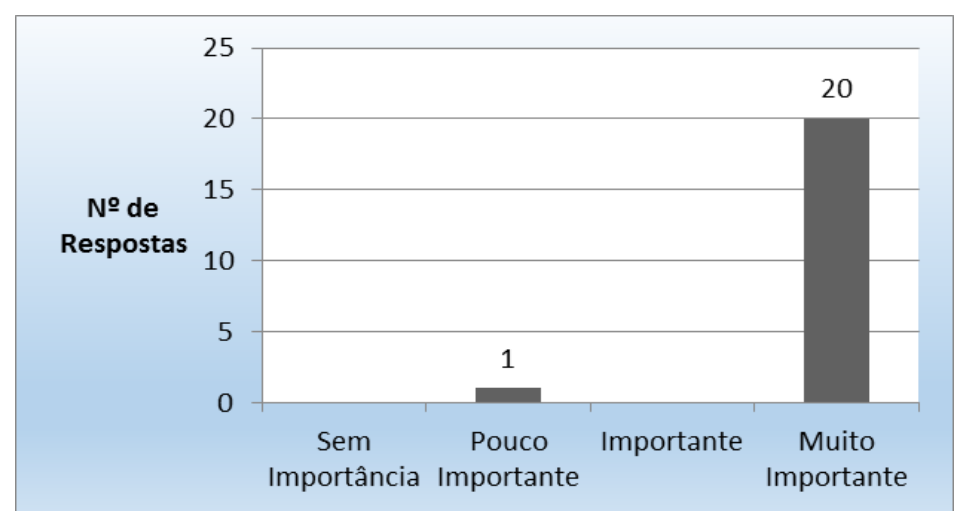

Gráfico 03 - Grau de importância da visita ao parque. Fonte: Pesquisa de campo (2015).

Sobre a trilha propriamente dita, quando questionados sobre qual a importância da realização da trilha para promover a educação ambiental, a maioria $(66,6 \%)$ respondeu ser muito importante, embora uma boa parte tenha respondido ser apenas importante $(23,8 \%)$ ou pouco importante $(9,5 \%)$ (Gráfico 04).

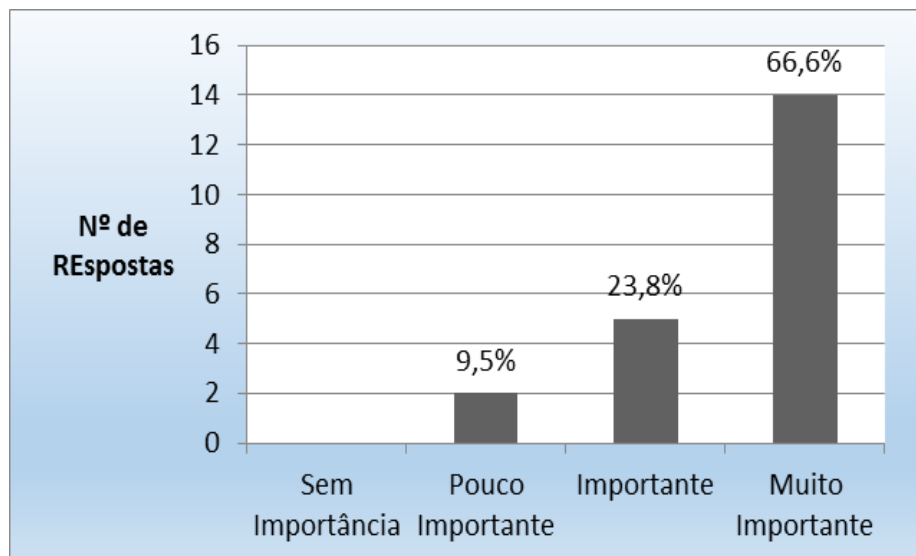

Gráfico 04 - Grau de importância da realização da trilha para a promoção da educação ambiental. Fonte: Pesquisa de campo (2015).

Uma vez questionados sobre a importância da realização da trilha para promover a consciência ambiental, maioria (90,4\%) consideram ser muito importante (Gráfico 05). Assim, comparando os gráficos 03, 04 e 05 percebemos que praticamente todos os entrevistados (20) consideram a visita ao parque importante (Gráfico 03), mas quando questionados sobre a importância da realização das trilhas esse número caiu para 14 (Gráfico 04). E no gráfico 05, um número de 19 entrevistados considerou a realização da trilha importante na promoção de uma 
consciência ambiental. Ou seja, nem todos concordam que a realização das trilhas é muito importante para promover a educação ambiental, mas consideram-na muito importante para promover uma consciência ambiental.

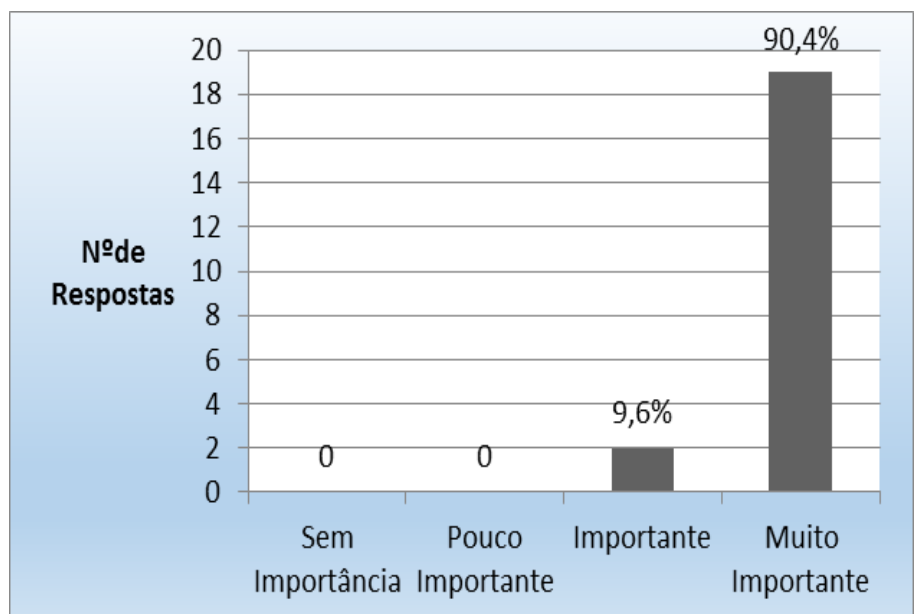

Gráfico 05 - Grau de importância de realização das trilhas para a promoção de uma consciência ambiental. Fonte: Pesquisa de campo (2015).

Isso pode ocorrer devido à importância dada a outras atividades realizadas também durante a visita, como por exemplo: a palestra de introdução, a visita à sala de exposição, entre outras atividades previamente planejadas (Figura 5). Todas essas outras atividades também objetivam promover uma consciência ambiental e de responsabilidade sobre o público participante, não somente as trilhas ecológicas, o que constitui objetivo da educação ambiental.

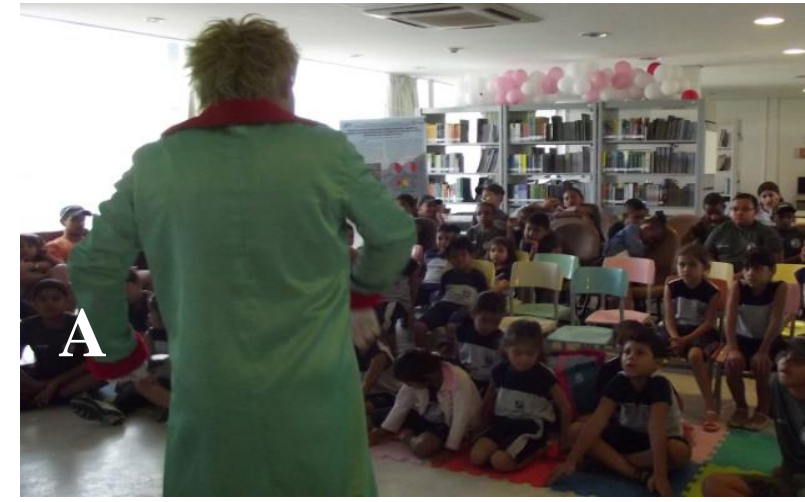

A - Contação de história na biblioteca.

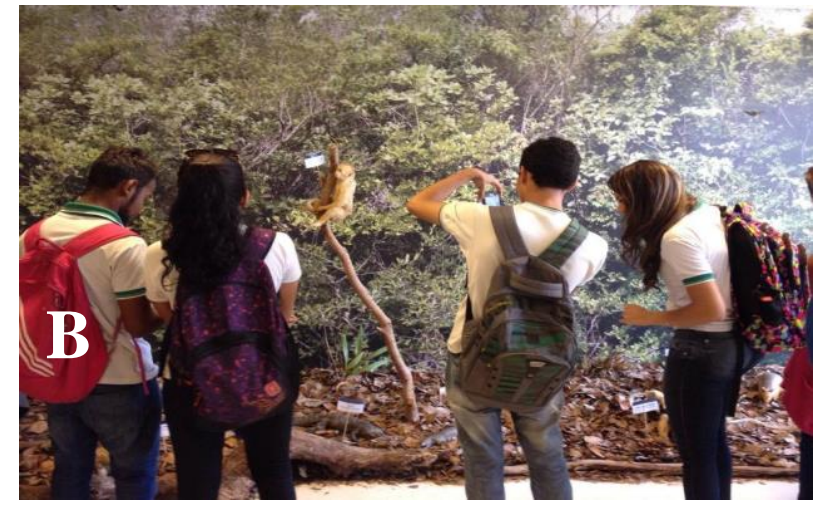

$\mathrm{B}$ - Visita à sala dos animais empalhados.

Figura 5 - Exemplos de outras atividades realizadas no Parque da Cidade (A e B). Fotos: Ana Clézia Simplício de Morais, Set./2015.

Quando questionados sobre quais áreas do conhecimento foram abordadas ao longo das trilhas através das falas dos guias, os participantes responderam conforme mostra o gráfico 06 abaixo. 


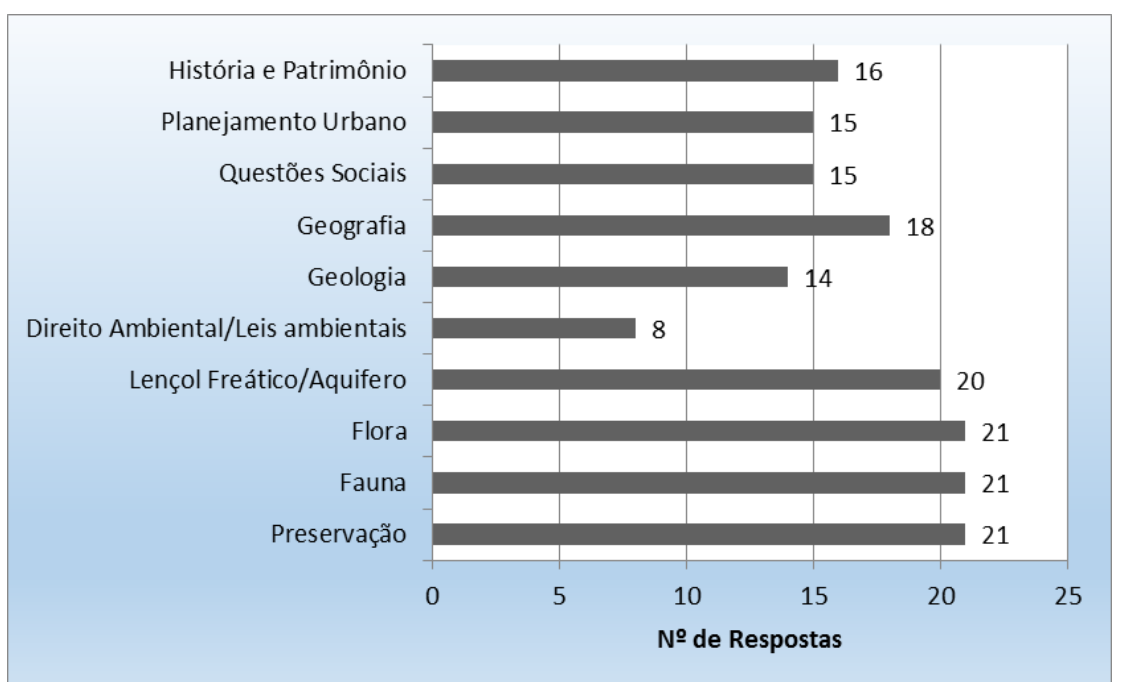

Gráfico 06 - Áreas do conhecimento exploradas pelo guia durante a trilha. Fonte: Pesquisa de campo (2015).

Assim, conforme o gráfico 06 acima, podemos dizer que maioria dos entrevistados falou que as áreas do conhecimento mais exploradas pelos guias dizem respeito à preservação, fauna, flora e lençol freático/aquífero. Isso de fato reflete a realidade uma vez que é dada forte ênfase nas funções desta unidade de conservação, ao longo do discurso dos guias, que é preservar a fauna, flora e o aquífero subterrâneo responsável por abastecer boa parte da cidade de Natal.

Por outro lado, podemos perceber que as áreas menos exploradas nas falas dos guias dizem respeito ao tema direito ambiental e geologia, o que de fato não são temas fáceis de serem explorados ao longo da trilha, porém não menos importantes.

\subsection{Avaliação do Guia da Trilha}

Foram feitas algumas perguntas com a finalidade de avaliar o guia da trilha quanto à sua capacidade de comunicação, domínio do conhecimento, metodologia utilizada e postura profissional. Abaixo encontramos algumas das categorias avaliadas e seus respectivos resultados (Gráfico 07 - A, B, C, D, E, F).

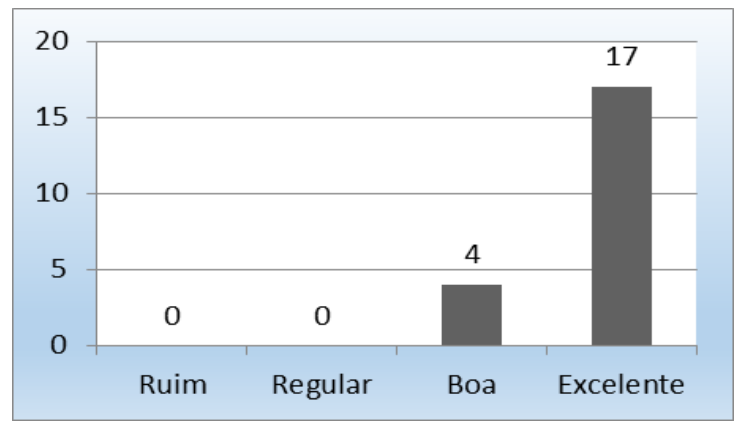

A - Receptividade e acolhimento do guia.

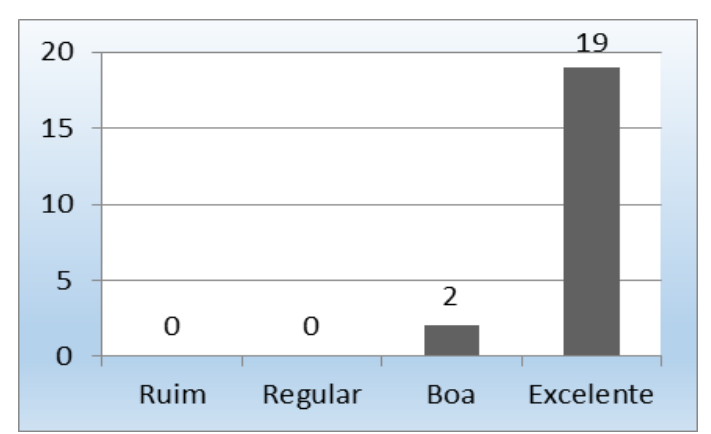

B - Orientações e instruções dadas pelo guia. 


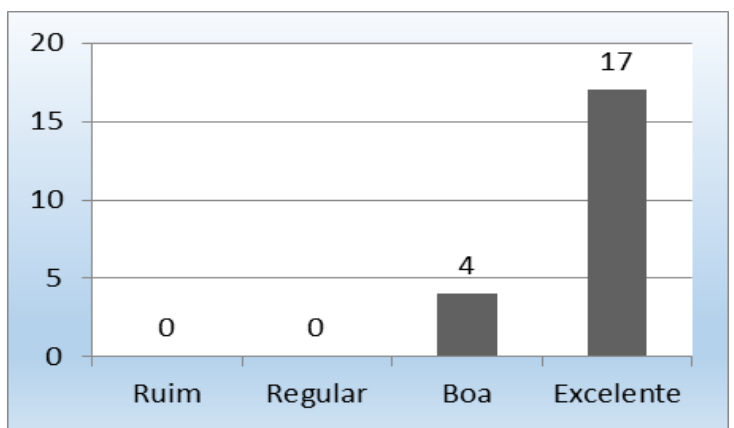

C- Linguagem utilizada pelo guia.

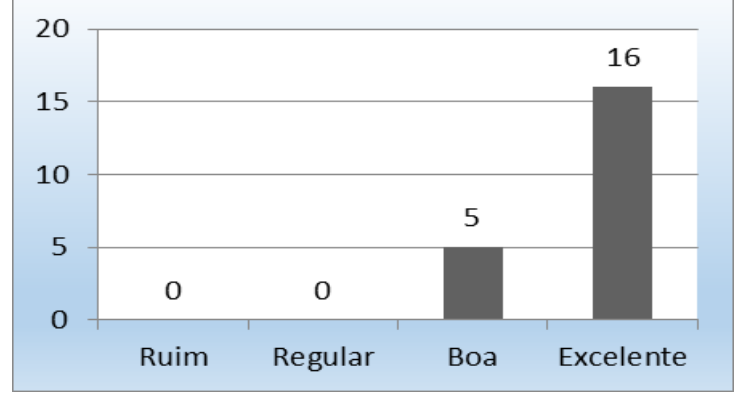

E- Metodologia utilizada pelo guia.
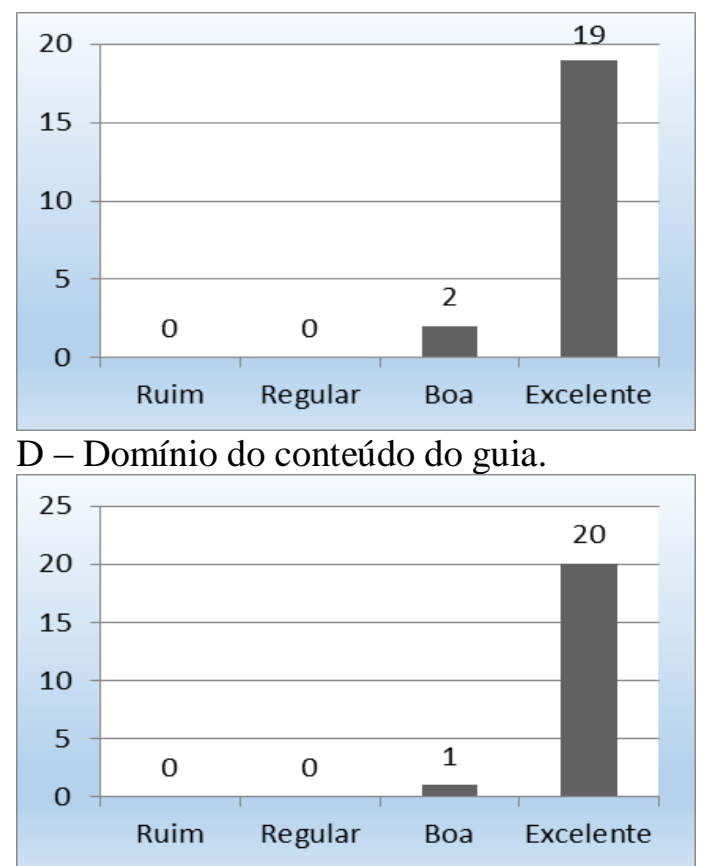

F - Postura profissional do guia.

Gráfico 07 - Avaliação do guia acompanhante e instrutor ao longo da trilha. Fonte: Pesquisa de campo (2015).

Avaliando os gráficos acima podemos concluir que, de modo geral, a avaliação do guia da trilha foi muito positiva, uma vez que, para todas as categorias avaliadas, a maioria dos entrevistados considerou excelente a conduta dos guias. Além disso, quando questionados sobre o papel da presença do guia ao longo da trilha $100 \%$ dos entrevistados consideram fundamental para o aprendizado da turma a presença do guia e de suas explanações a respeito de assuntos diversos. O guia, portanto, exerceu papel fundamental no aprendizado e sensibilização do grupo.

Apresentou bom desempenho na forma de recepção e acolhimento do grupo, passando pelo bom domínio do conteúdo e linguagem adequada, bem como sua postura profissional apropriada. E também quando se perguntou sobre a influência da metodologia utilizada pelo guia no aprendizado das informações também 100\% dos entrevistados afirmou ter influenciado positivamente. Ou seja, embora alguns tenham achado a metodologia boa e não excelente ainda assim a consideraram uma influência positiva para o aprendizado do grupo.

Vale salientar, entretanto, um aspecto da recepção dos grupos visitantes. Observou-se que ao chegarem ao parque o grupo não tem um local adequado para o acolhimento, ficando numa área pequena e limitada no pórtico de entrada. Essa área é considerada inadequada uma vez que não há espaço suficiente para um grupo grande e nem para o guia expor com segurança e conforto as instruções antes de iniciar as trilhas (Figura 6). Nessa área transitam veículos que entram e saem do Parque, constituindo também um fator de risco aos visitantes e funcionários que necessitam, muitas vezes, dividir esse espaço com os veículos. 


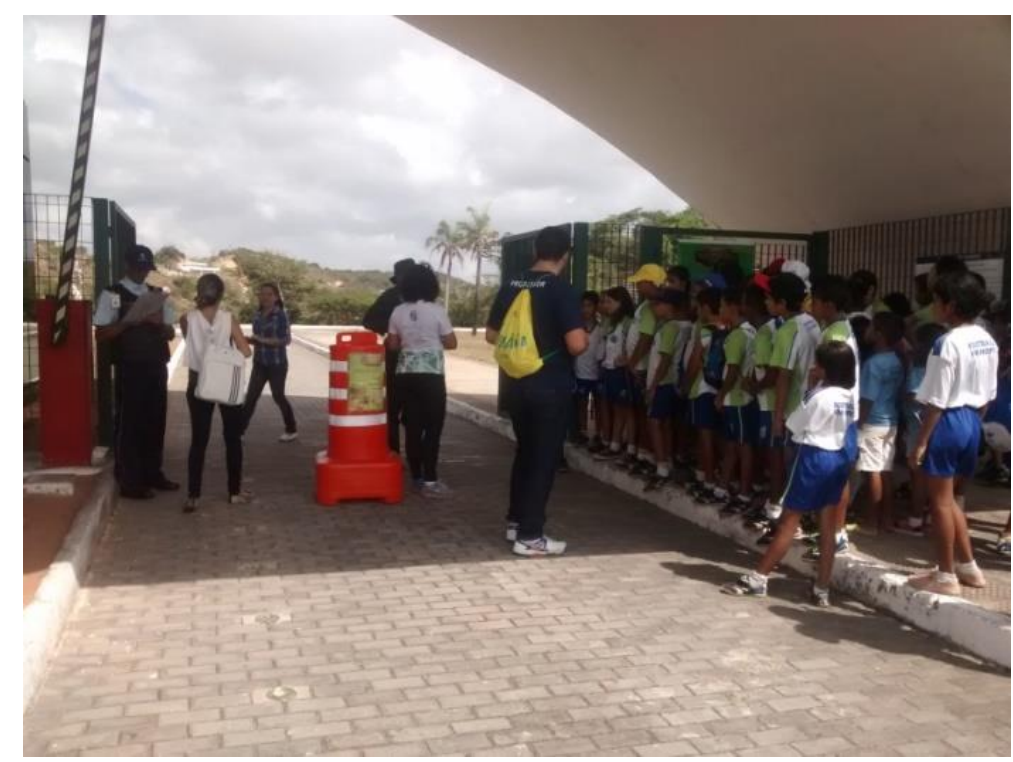

Figura 6 - Recepção de um grupo de visitantes. Foto: Ana Clézia Simplício de Morais (Ago./2015).

Assim, sugere-se que seja construída uma estrutura de recepção aos grupos próximos a área da portaria, onde os visitantes possam sentar em segurança e ouvir atentamente as instruções da trilha sem que outros elementos tirem a atenção dos mesmos.

\subsection{Avaliação do conhecimento adquirido pelos entrevistados}

Quando questionados sobre o nível de conhecimento adquirido ao longo da visita na trilha pudemos ter um retorno bastante positivo onde maioria dos entrevistados afirma ter aprendido muitas coisas novas (Gráfico 08).

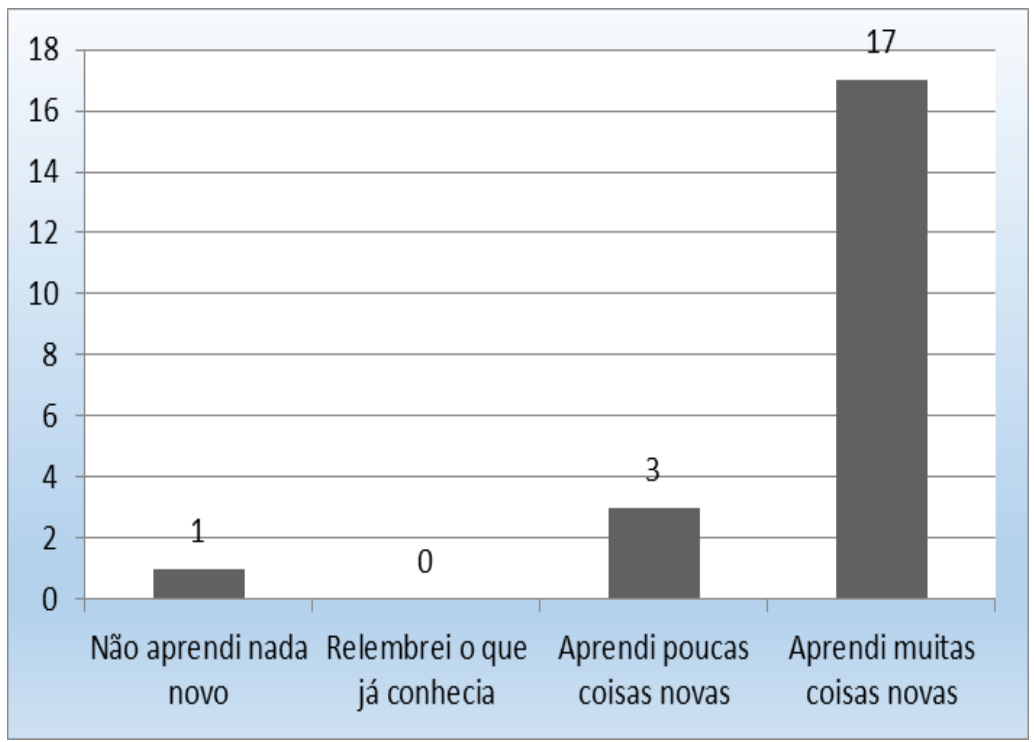

Gráfico 08 - Nível de conhecimento adquirido pelos participantes. Fonte: Pesquisa de campo (2015). 
Isso revela que há uma boa diversidade de informações exploradas pelos guias ao longo das trilhas, com curiosidades a respeito de aspectos locais, sobretudo da fauna e flora, que eram desconhecidas pelos visitantes. Um aspecto bastante interessante abordado ao longo das trilhas é a presença de um casal de corujas buraqueiras, onde os visitantes gostam muito de ver e fotografar, além de aprender sobre os hábitos deste animal, que é muito bem explanado pelos guias.

Quando questionados sobre o seu nível de motivação para uma mudança de postura ambiental após a realização da trilha maioria dos entrevistados afirmaram estar muito motivados e outros apenas motivados (Gráfico 9). Isso indica, teoricamente, um efeito positivo da trilha ecológica sobre as atitudes dos entrevistados, repercutindo sobre uma mudança de postura. Ou seja, a realização da trilha ecológica sensibilizou o entrevistado para as questões que envolvem a problemática ambiental bem como o seu papel influenciador, através de suas atitudes ou ausência delas, a ponto de sentirem-se muito motivamos para uma mudança de postura.

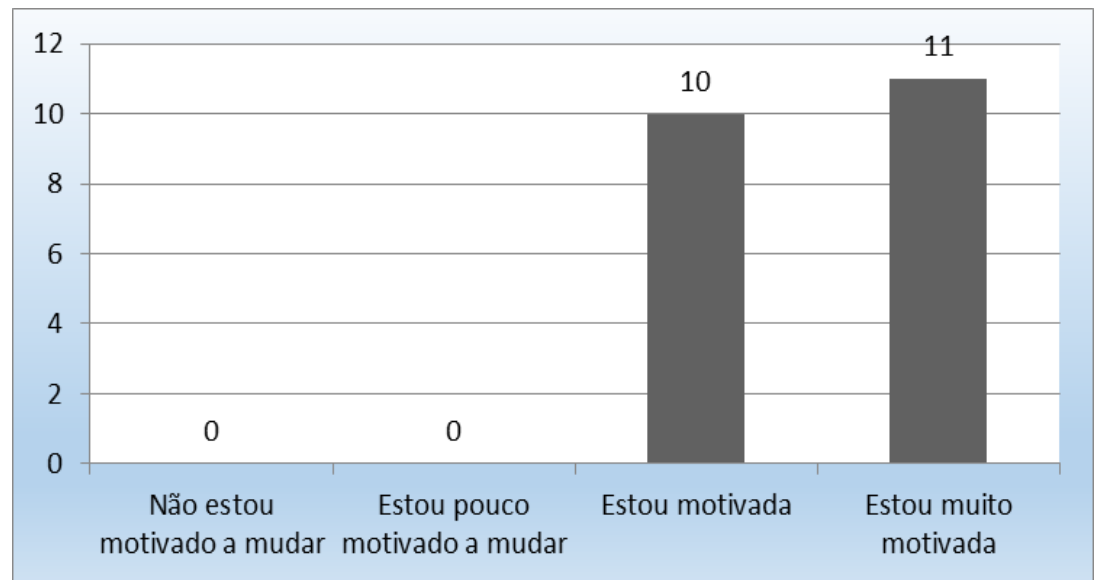

Gráfico 09 - Nível de motivação para uma mudança de postura. Fonte: Pesquisa de campo (2015).

Questionou-se ainda aos entrevistados quais áreas do conhecimento eles aprenderam mais informações novas, e as resposta identificaram as categorias fauna, lençol freático/aquífero e flora (Gráfico 10). Há uma dedicação maior por parte dos guias sobre informações da fauna e flora, uma vez que estes elementos são os mais abundantes visualmente na área de trilha. Além disso, os guias dão ênfase especial sobre o papel do lençol freático existente no subsolo do parque devido à sua importância no abastecimento de parte da população de Natal/RN, falando também das problemáticas envolvidas na sua preservação. 


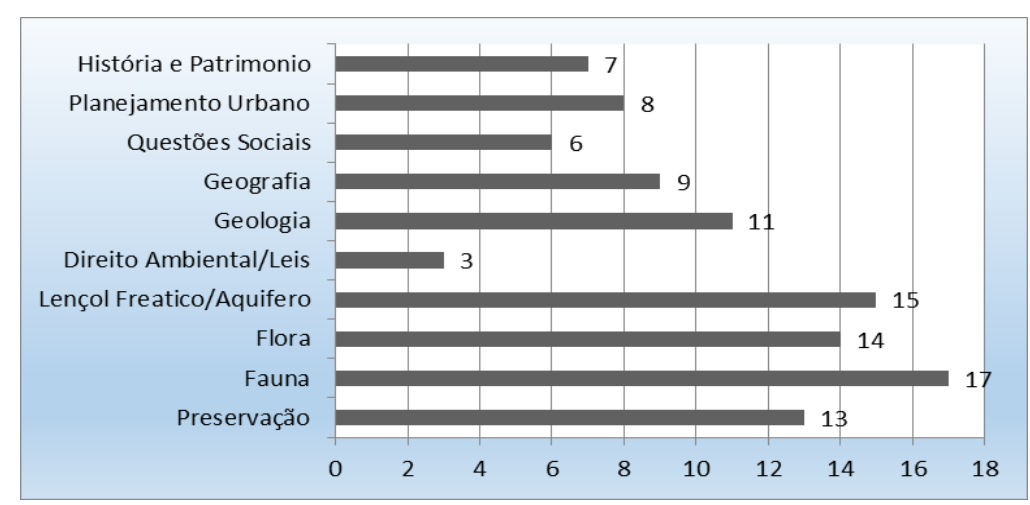

Gráfico 10 - Áreas do conhecimento em que se aprenderam mais informações novas. Fonte: Pesquisa de campo (2015).

Os entrevistados identificaram quais áreas do conhecimento eles desejariam obter maiores conhecimentos, sendo as principais áreas apontadas por eles: direito ambiental, planejamento urbano, geografia e história e patrimônio identificadas no gráfico 11.

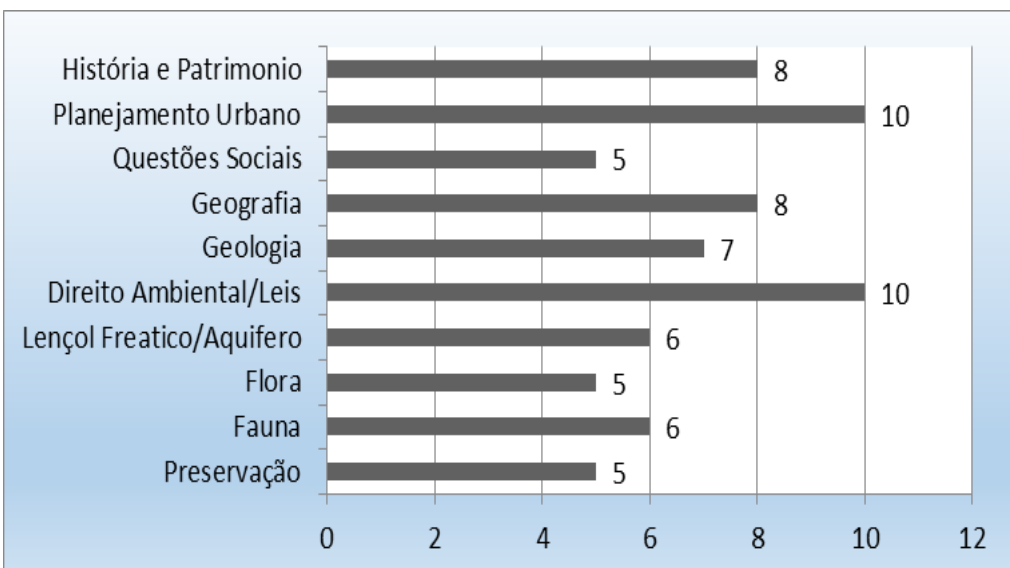

Gráfico 11 - Áreas do conhecimento em que gostaria de se aprender mais coisas novas. Fonte: Pesquisa de campo (2015).

Como se observa as áreas onde se desejou obter mais conhecimento foi justamente àquelas menos exploradas pelos guias. Indicando que é possível explorar mais informações, curiosidades e aspectos diversos associados a essas temáticas identificadas pelos entrevistados.

\section{CONSIDERAÇÕES FINAIS}

As trilhas ecológicas do Parque da Cidade representam uma poderosa ferramenta para a promoção da educação ambiental, com efeitos sobre a sensibilização do visitante que realiza as trilhas guiadas. Destacamos aqui alguns pontos positivos que contribuíram para que essa ferramenta pudesse ser utilizada de modo eficaz, tais como: uma ótima estrutura física das trilhas pavimentadas; sinalização adequada e excelente estado de conservação das trilhas; e excelentes 
guias capacitados a instruir ao longo das trilhas. Além disso, o parque inteiro constitui-se de uma estrutura adequada a práticas de atividades diversas de educação ambiental e todos os elementos presentes na visita acabam influenciando para uma educação transformadora.

Sobre os pontos a serem melhorados destacamos: a construção de uma área de recepção adequada aos grupos visitantes; uma adequação e melhoria da sinalização das trilhas, com aumento no número das placas proibitivas ao longo das trilhas e contemplando pelo menos outra língua estrangeira; treinamento periódico com os guias das trilhas através de cursos de capacitação a fim de manter a atualização e qualidade das informações; manutenção periódica da estrutura física das trilhas, evitando-se abertura de buracos, acúmulo de areia e ausência de informações relativas à segurança dos visitantes.

Em se tratando das trilhas, especificamente, podemos considerar que o guia recebeu um papel de destaque através da sua função educativa e formativa na realização das trilhas e no que concerne ao objetivo da mesma, contribuindo para a transmissão de novos conhecimentos bem como para a promoção de uma reflexão que gera a consciência ambiental. Assim, o guia desempenhou importante papel ao fazer o visitante perceber o ambiente como um espaço natural alvo de interação e modificação social. Compreender o meio em que se vive não é concebido, portanto, independente da ação do homem como um ser social.

Diante disso, torna-se importante que os guias busquem estabelecer essa relação em seus discursos ao longo das trilhas, realizando mais estudos/pesquisas sobre o parque, procurando participar de minicursos, palestras relacionadas ao ambiente, como forma de se aprimorarem mais. Que os guias busquem estudar temáticos como as que foram identificadas pelos próprios entrevistados: questões sociais, história e patrimônio, planejamento urbano e direito ambiental. Todas essas áreas abordam, direta ou indiretamente, sobre como o homem estabelece interações com o meio, modificando-o.

A excelente avaliação dos guias reforça o papel transformador desse agente educativo quando percebemos que todos os entrevistados consideraram fundamental a presença dele para o melhor aprendizado do grupo. E todos avaliaram positivamente também a metodologia utilizada, com destaque para uma linguagem clara e objetiva, sem termos demasiadamente científicos e com ilustrações e analogias que permitiram os visitantes compreenderem processos naturais que parecem, a princípio, complicados de se entender.

Por fim, considerando o papel da trilha como uma ferramenta de educação ambiental verificou-se que esta atingiu seu objetivo. Isso é possível de perceber quando observamos que a maioria declarou ter aprendido muitas informações novas em diversas áreas do conhecimento, a 
maioria deseja aprender mais informações novas sobre áreas diversas e que se sentem motivamos ou muito motivados a mudar sua postura frente às necessidades de preservação ambiental.

\section{REFERÊNCIAS}

BRASIL. Ministério do Meio Ambiente. Lei Federal n ${ }^{\circ}$ 9.985/2000. Brasília, 2000. Disponível em: <http://www.planalto.gov.br/ccivil_03/LEIS/L9985.htm>. Acesso em: 25/08/2016.

DI TULLIO, Ariane. A abordagem participativa na construção de uma trilha interpretativa como uma estratégia de educação ambiental em São José do Rio Pardo - SP. Dissertação (Escola de Engenharia de São Carlos da Universidade de São Paulo). São Carlos: 2005.

GADOTTI, Moacir. Pedagogia da Terra. São Paulo: Editora Peirópolis, 2000.

JACOBI, Pedro. Educação ambiental, cidadania e sustentabilidade. Março/2003. Cadernos de Pesquisa, n.118, p.189-205, março/2003. Disponível em: <http://www.scielo.br/pdf/cp/n118/16834.pdf>. Acesso em 25/08/2016.

INSTITUTO BRASILEIRO DE ANÁLISES SOCIAIS E ECONÔMICAS - IBASE. Nahyda Franca (Coord.). Educação ambiental em unidades de conservação. 2006. Disponível em: < http://www.ibase.br/userimages/ap_ibase_educacao_01c.pdf>. Acesso em 25/08/2016.

LAYARGUES, Philippe Pomier. Educação para a gestão ambiental: a cidadania no enfrentamento político dos conflitos socioambientais in Loureiro, Carlos Frederico Bernardo, LAYARGUES, Philippe Pomier, Castro, Ronaldo Souza de (orgs.). Sociedade e meio ambiente: a educação ambiental em debate. Cortez, São Paulo, 2000.

MEDEIROS, Fernando. Parque da Cidade: um lugar, muitas experiências. Parque da Cidade em Revista. Ano1, n.1, 2015. Disponível em: < http://natal.rn.gov.br/semurb/revistas/file/revista_parque_201506.pdf >. Acesso em 01/09/16.

NATAL. Prefeitura Municipal do Natal. Localização. Parque da Cidade Dom Nivaldo Monte. 2014. Disponível em: 〈http://www.natal.rn.gov.br/parquedacidade/paginas/ctd-482.html>. Acesso em: 10/09/16.

QUINTAS, J. S. Pensando e Praticando a Educação Ambiental na Gestão do Meio Ambiente. IBAMA, Brasília, 2002.

QUINTAS, J. S. (Org.). Pensando e praticando a educação ambiental na gestão do meio ambiente. 3. ed. (Coleção meio ambiente, Série educação ambiental). IBAMA, Brasília, 2006 (pp.161-198).

REIGOTA, Marcos. O estado da arte da pesquisa em educação ambiental no Brasil. Pesquisa em Educação Ambiental, v.2, n.1. p.33-66, 2007. Disponível em: <www.revistas.usp.br/pea/article/viewFile/30017/31904>. Acesso em: 10/09/2016.

SAMPAIO, Shaula Maíra Vicentini de; GUIMARÃES, Leandro Belinaso. Educação ambiental: tecendo trilhas, escriturando territórios. Educação em Revista. Belo Horizonte. v.25, n.3, p. 353368. 2009. Disponível em: < http://www.scielo.br/scielo.php?script=sci_arttext\&pid=S010246982009000300017>. Acesso em: 10/09/2016.

SANTOS, C. M.; LOPES, E. A. DE M.; PASSIPIERI, M.; DORNFELD, C. B. Oficina de interpretação ambiental com alunos do ensino fundamental na "trilha do Jatobá em Ilha Solteira, SP. Revista Eletrônica de Educação, v.6, n.2, nov., 2012. Disponível em: < 
http://www.reveduc.ufscar.br/index.php/reveduc/article/viewFile/218/201>.

em: 01/08/2016.

SAUVÉ, Lucie. Educação ambiental e desenvolvimento sustentável: uma análise complexa. Revista de Educação Pública, 1997. Disponível em: < http://www.serrano.neves.nom.br/MBA_GYN/edsoc10.pdf >. Acesso em: 31/08/2016.

SAUVÉ, Lucie. Educação ambiental: possibilidades e limitações. Educação e Pesquisa, São Paulo, v.31, n.2, p.317-322, maio/ago. 2005. Disponível em: < http://www.scielo.br/pdf/\%0D/ep/v31n2/a12v31n2.pdf>. Acesso em: 26/09/2016.

SORRENTINO, Marcos; TRAJBER, Rachel; MENDONÇA, Patrícia; FERRARO JUNIOR, Luiz Antônio. Educação ambiental como política pública. Educação e Pesquisa, São Paulo, v. 31, n. 2, p. 285-299, maio/ago. 2005. Disponível em: 〈http://www.scielo.br/pdf/ep/v31n2/a10v31n2.pdf>. Acesso em: 31/08/2016.

STEIL, C. A.; CARVALHO, I. C. M.; PASTORI, E.O. Educação ambiental no Rincão Gaia: pelas trilhas da saúde e da religiosidade numa paisagem ecológica. Educação, Porto Alegre, v. 33, n.1, p.54-64, jan./abr. 2010. Disponível em: < http://revistaseletronicas.pucrs.br/ojs/index.php/faced/article/view/6783/4947>. Acesso em: 31/09/2016.

TOMAZELLO, Maria Guiomar Carneiro; FERREIRA, Tereza Raquel das Chagas. Educação ambiental: que critérios adotar para avaliar a adequação pedagógica de seus projetos? Ciência \& Educação, v.7, n.2, p.199-207, 2001. Disponível em: < http://www.ambiente.sp.gov.br/wp-content/uploads/cea/Texto_avaliacao_ea.pdf>. Acesso em: 08/06/2016.

ZANETI, Izabel.C.B. B. Educação Ambiental, Resíduos sólidos urbanos e Sustentabilidade: um estudo de caso sobre o sistema de gestão de Porto Alegre/RS. Tese de Doutorado. Centro de Desenvolvimento Sustentável/UnB, 2003.

Recebido em: 07/08/2017

Aceito para publicação em: 21/12/2017 